\title{
Evaluating Environmental Sustainability in Iranian Primary Schools through Design Principle Approach
}

\author{
Bushra Abbasi $^{1}$, Mohammad Ali Khan Mohammadi ${ }^{1} \&$ Mohadeseh Mahmoudi $^{2}$ \\ ${ }^{1}$ School of Architecture and Environmental Design in Iran University of Science and Technology, Tehran, Iran \\ ${ }^{2}$ Faculty of Built Environment, University of Malaya, Kuala Lumpur, Malaysia \\ Correspondence: Mohadeseh Mahmoudi, Faculty of Built Environment, University of Malaya, Kuala Lumpur, \\ Malaysia. E-mail: mohadeseh.mah@gmail.com
}

Received: July 28, 2013 Accepted: August 12, 2014 Online Published: September 29, 2014

doi:10.5539/ass.v10n19p206

URL: http://dx.doi.org/10.5539/ass.v10n19p206

\begin{abstract}
As the first educational space children spend most of their daily time in, Primary School is the best start point of fostering the priorities of environmental sustainability. Lack of consideration in this field is clearly showing the absence of environmental sustainable requirements in the guiding design principles. Yet, what are the shortcomings of design principles in Iranian primary schools? This paper aims to define the shortcomings of design principles in Iranian primary schools on the basis of environmental sustainability and present recommendation which can be considered by Iranian school designers. The adopted method of research is case study approach, and answering the research questions by qualitative data collection. To reach the aim of research, importance of environmental sustainability in a primary school is highlighted and the effect of governmental design principles on the design of school building will be reviewed through relevant literature and reliable documents. Then, environmental considerations of the design principles presented by State Organization of School Renovation, Development and mobilization in Iran are evaluated on the grounds of LEED for school rating system. In addition, Roshangar Primary school which was successfully built in accordance to the mentioned Iranian design principle is selected as the case study of research. Through a visual analysis, current practice of these design principles can be examined and presented in a clear view. The shortcomings of the above mentioned design principles will be discovered afterwards and recommendations will be presented in the conclusion of research.
\end{abstract}

Keywords: environmental sustainability, design principles, Roshangar Primary School, Tehran

\section{Introduction}

Protecting the environmental capabilities of planet earth, paying attention to environmental needs of future generation and overall, environmental sustainable architecture, has become one of the most important discussions of today's scientific and professional gatherings. In order to promote public knowledge level and social participation towards sustainable development, researcher's attention was attracted to public spaced in hall and educational spaces in particular. Primary School, as the first social space a child experiences, can have an effective role in training and fostering sustainable priorities of environment to future decision makers of a nation (Nair \& Fielding, 2005). Therefore, the existence of environmental sustainability in school architecture becomes so important.

Aesthetical priorities, budget of the school builder, user's requirements and the proficiency of the school's architect, are all the effective factors of school's architecture. Yet, the design principles set and presented by the State Organization of School Renovation can be known as the most effective factor in school architecture of Iran (Zahedi, 2014). The approach of this Organization in the last decade, and the control it has over the construction of school building in this developing country, makes a researcher believe that improvement of organizational design principles will lead to the improvement of school architecture.

In this study, the design principles of State Organization of School Renovation in Iran are examined through an environmental approach to explore the current shortcomings in the principles of primary school. It is hoped that by fulfilling the defined shortcomings, educating in a sustainable environment becomes a possibility for Iranian children. 


\subsection{Environmental Sustainability in Iran}

Sustainability means capable of being Sustained, or best described through Brundtland Report at 1987; "Humanity has the ability to make development sustainable. To ensure that it meets the needs of the present without compromising the ability of future generation to meet their own needs...it is a process of change..." (Sassi, 2006, p. 3)

Environmental crises, which involved the world after industrial revolution, led to the formation of design principles under the heading of Environmental Sustainable Architecture. These principles were in line with retaining the non-renewable sources of the earth and using environmental capabilities without destroying the opportunities of future generation. Iran, also, under the effects of the above said crises has no way other than accepting and developing sustainability according to the requirements and needs of Iranian society.

"A sustainable development is a development which is based on a commitment for creating better life for all people. In order to reach higher quality of life, much more attention should be paid towards immaterial properties, human interrelationship and environment, and this would not be achieved except by better acquirement of knowledge and promotion of culture". Sustainable foundations have been successful in achieving its special place in academic gatherings of Iran, yet professional field of architecture has left behind. Professional architects should also desultorily put attention on the priorities and principles of sustainable architecture in order to reach sustainable development in Iran. However, as development can only be gained through public support and social participation (Lahsayeezadeh, 2007), Social acceptance is needed for sustainable development to achieve its correct process. It is only through this path that sustainability could present its values and priorities, practically and professionally, using the framework of sustainable architectural principles.

\subsection{Necessity of Environmental Sustainability in Primary Schools}

Acceptance requires cognition, and primary school is a suitable environment to gain cognition. Educational space of primary school can be the best starting point for social elucidation towards environmental sustainable priorities. "Primary School" is generally known to be a particular educational space for a certain age group, yet, it is also the building which young children spend most of their daily time, or in other words, most of their childhood, in! "... Architectural Design of School, in that sense is a very important element of mental education"(Tominga, 1995, p. 5).

"In 1993, Fedricho Mayor, former president of UNESCO officially informed the world of arranging two international committees on 'culture and development' and also on 'teaching and training' in the $21^{\text {st }}$ Century" (Dresner, 2008, p. 8). It was through the detailed, comprehensive study of these committees that inefficiency of educational methods and their low quality was introduced as the drawback of sustainable development. Committees concluded the "Learning Method" as the first stage in the remedy of teaching, which was again based on four factors; 1) Learning to live together, 2) Learning to learn, 3) Learning to practice, 4) Learning to be. Education, as the most effective device of societies for entering future challenges, has finally achieved a worldwide consensus and is now accepted as the most important factor in changing the way of human thinking and behavior. "Education in that sense will be applied in economic growth, life quality, promoting knowledge, providing job opportunities and increasing the local production"(Khan Mohammadi, 2014). This is the exact reason why education has managed to gain a unique degree in societies. The importance of sustainable education is not limited to academic researches, but is also agreed on in practice, through international institutes. In 1997, United Nations General Assembly approbated a statement with a focus on the $21^{\text {st }}$ agenda. This statement introduced the educational system in whole, and primary education in particular, as the foundational base for reaching sustainable development, and therefore, pressured on the necessity of over reviewing the educational orientations of all countries in the world (Curlwell, 2005). Sustainable education, in its extensive concept, will have the capability to establish a strong bridge, as a reliable device, between classroom and society and between classroom and market of future decades.

The start point of learning democracy, public engagements and social activities is in the primary school, and it is only succeeded though educational process and its continuity(Khan Mohammadi, 2014) . Therefore, the most suitable place for fostering the principles and priorities of environmental sustainability to children, as the most effective part of society, can be known as the school itself. Training values of sustainability to children can simply be accomplished through architecture of the primary school building (Stevenson, 2002), and it is this logic that gives architecture the ability of teaching sustainability. 


\section{Research Method}

The most efficient way to discover the shortcomings of school design principles set by the "State Organization of School Renovation in Iran", is through comparative examination. "LEED 2009 for Schools New Construction and Major Renovations" is a guide line presented by an internationally known sustainable rating system of U.S. Green Building Council in year 2009. Through comparison between Iranian design principles and international guide lines, shortcomings of open and close spaces in primary schools will be discovered. In addition, Roshangar Primary School, is part of Roshangar educational complex which was successfully built based on the design principle of State Organization of School Renovation in Iran, is selected as a case study to analyze the result of established design principles in practice. This primary school was selected as the case study of this research because apart from being completely designed in accordance to the above mentioned Iranian design principles, it has managed to receive the award of education and design in year 2010 from the organization of School Renovation. It is also located in Tehran as the capital and the pioneer of today's architectural movements in Iran. Being constructed in Shahrak Gharb neighborhood of Tehran, which is known for its fine urban design and wide public green spaces, will help the result of comparison analysis even more reliable for Iranian young planners and designers to use in the rest of the city, and the country. The other reason of this selection is that Roshangar Primary School is consumed by the average level members of the society which are mainly affected by indirect educating tools of sustainable development and are mostly needed to gain cognition towards sustainable priorities in order to achieve environmental sustainability in a society. The following sections demonstrate this process.

\subsection{Design Principle Approach}

\subsubsection{Design Principles for School}

The international LEED organization, which is abbreviation of 'Leadership in Energy Environmental Design', pointed out the importance of sustainability in educational spaces in 2009 and provided a guide line in order to achieve sustainability in schools. This guide line could be used as a reliable source to evaluate sustainability in schools all over the world. Appendix A illustrates LEED guide line for design of environmental sustainable school. Design principles for Iranian schools are provided by State Organization of School Renovation. Therefore, a complete report on principles and guide lines published by this organization for the close spaces of Iranian primary schools is presented in Appendix B. Furthermore, the standards for required open space in primary school are shown in Appendix C.

2.1.2 Comparison of LEED 2009 for School and Design Principle of State Organization of School Renovation in Iran

Table 1. Similarities between LEED 2009 for school and Iran design principles for school

\section{International LEED rating system for school}

\begin{tabular}{llll}
\hline Main Branch & Factor & Open Space & Close Space \\
\hline Sustainable site & Maximizing open space & $\begin{array}{l}\text { demanding Landscape, using } \\
\text { flower boxes and trees }\end{array}$ & -------- \\
\hline Sustainable site & Multipurpose use of facilities & $\begin{array}{l}\text { demanding Queue up space and } \\
\text { playground }\end{array}$ & - --------- \\
\hline Sustainable site & $\begin{array}{l}\text { Creating appropriate parking } \\
\text { capacity }\end{array}$ & demanding Vehicle parking space & --------- \\
\hline Sustainable site & Site development plan & $\begin{array}{l}\text { Preserving space for future } \\
\text { development }\end{array}$ & -------- \\
\hline Sustainable site & $\begin{array}{l}\text { Providing appropriate public } \\
\text { transportation access }\end{array}$ & $\begin{array}{l}\text { demanding Linking path for public } \\
\text { transport }\end{array}$ & --------- \\
\hline Sustainable site & $\begin{array}{l}\text { Providing space for bicycle } \\
\text { storage and changing rooms }\end{array}$ & -------- & $\begin{array}{l}\text { demanding Student } \\
\text { Changing Room }\end{array}$ \\
\hline
\end{tabular}

Principles of State Organization of School Renovation, Development and mobilization for School Design

demanding Landscape, using

demanding Queue up space and

demanding Vehicle parking space

Preserving space for future

elopmen 
A review on principles presented by State Organization of School Renovation shows that the mentioned principles are more similar to a physical programming of space! Moreover, it is evident that the presented principles for Iranian primary school design have not considered the quality of design of this space and they have just pointed to the necessity of existence of a particular space in a primary school. Even though, the demonstrated design principles, or better said as "physical program", includes valuable environmental points, lack of attention to environmental sustainable priorities is undeniable. In other words, the environmental attention discovered in the current Iranian design principles, show the importance of this issue for the above mentioned organization, yet, the arrangement and the concept of their established principles clearly presents their lack of knowledge in this field. There are seven main branches in LEED 2009 for schools (Appendix A), yet only the branch of 'Sustainable Site' had 6 items in common with Iranian organizational design principles. It's clear that the common points are mostly due to open spaces, rather than close spaces. In table1, common principles between LEED and State Organization of School Renovation in Iran are specified:

\subsection{Case Study Analysis}

Exploring the effect of Current Iranian Primary School's Design principles on the design of a school building, and examining their shortcomings in accordance to the requirements of Sustainable Architecture, can be clearly achieved through analyzing the close and open spaces of a school which is Certificated by the State Organization of School Renovation. Different schools have been built in various cities of Iran recently, all following the above mentioned principles, yet, selected school of this study is a school called Roshangar Primary School, located in the north-west of Tehran. As the capital city of Iran, Tehran is usually known and used for international examples. It also contains most of the acceptable design samples of the country and plays as a pioneer for any kind of development in Iran. Therefore, findings based on an acceptable architectural example of Tehran will be spotted and used in the rest of the country as well as Tehran Itself. Figure1 shows the location of Shahrak Gharb in the capital city of Tehran.

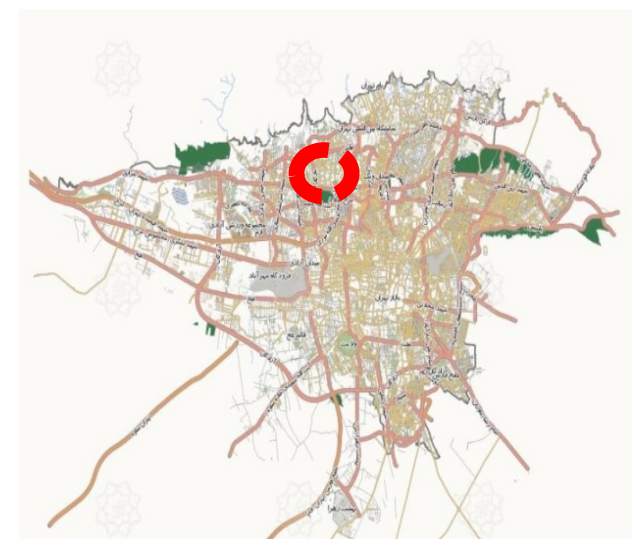

Figure 1. Location of Shahrak Gharb in Tehran

As mentioned, Roshangar Primary School is constructed in the Roshangar Educational Complex, located in north-west of Tehran. Neighborhood of Roshangar's locating place is called Shahrak Gharb which is known for its fine urban design and wide public green spaces. Figure2 shows the location of Complex in the conjunction point of Eivanak Boulevard and South Golafshan St, in the Western part of Shahrak Gharb. This school is a private school, with average financial fees and funding opportunities, which serves middle class families of Iranian society who are willing to receive better education for their children. Roshangar Primary School is designed as a two story building with an underground floor level and wide multifunctional spaces. It contains 12 classrooms, a workshop, a science laboratory, a computer room, an art class, a library and a dining hall in total area of $2359.6 s q^{2}$. As shown in figure 3, the sports hall of Primary school is outside of the school's main building. While Primary school is located in the south-east side of the complex, the sports hall is in the north-west side. Constructing a separate, equipped sports hall with facilitated changing rooms shows designer's attention on the importance of physical activity for young children. The multi-functional hall in the underground floor level can also be occasionally used as a gym hall, gaining enough lighting and ventilation from School's central garden. 62 employees, including 30 teachers are employed in Roshangar Primary schools and 360 Pupil are gaining education in it. This research aims to examine the case study as detailed as possible in the limits of visual analysis, and on the grounds of LEED 2009 international guide lines for open and close spaces of Primary 
Schools. Since part of the mentioned guide lines are related to the construction process and is not with in the research's limitations in data collection, it has not been considered in the final analysis results.

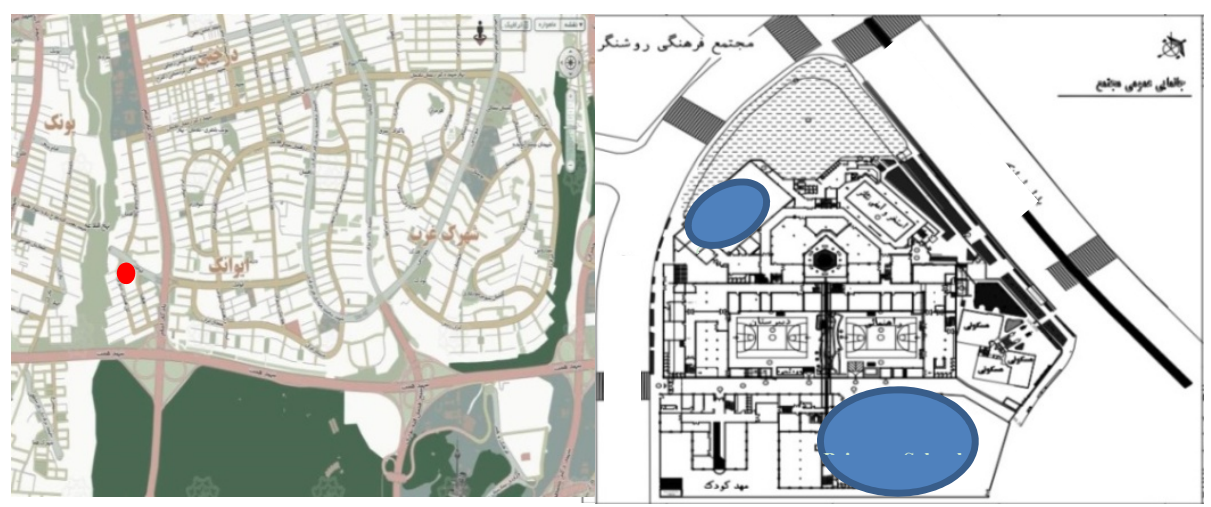

Figure 2. Location of Roshangar Educational Complex in Shahrak Gharb

Figure 3. Location of primary school and sports hall in the Roshangar Educational Complex

\subsubsection{Data Collection}

\section{Environmental Sustainability in Open Spaces of Roshangar Primary School}

The yard of Primary School, with an area of $188 \mathrm{~m}^{2}$, is located in the south east of the complex. Two lines of green space can be spotted in the south and east of the yard. The rest of the yard is plain playground covered with flat stones. Lack of green natural space in the school yard can be spotted in figure 4 .

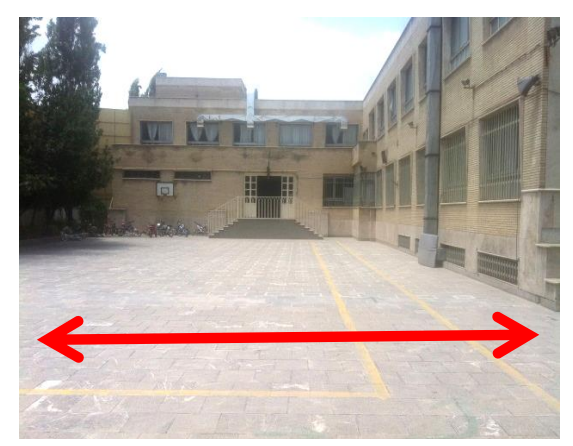

Figure 4. Lack of landscaping in the school yard

Landscaping and natural spaces are considered as the primary necessities of environmental sustainable architecture. Planting and greenery not only improve the space quality, but improves the ability of learning in young children. "It is nature itself that can teach our children about respecting and relating with their natural environment" (Lynch \& Hack, 1984, p. 74). While Child is learning to respect the nature, he/she will also learn to communicate with the society and respect other humans (Beer, 2000). Attention to green, natural space in Roshangar Primary School is not enough. Even though the school designer has tried to combine the yard with some green space, the combination hasn't been successfully practiced and it seems like the yard has pushed its green parts to its sides as a narrow green line which is unlikely to be used, or even noticed, by children. On the other hand, figure 5 shows that the designer has tried to fulfill this shortcoming at the opposite site of the yard with moving the green line away from the wall and considering resting spaces for children in its sides with a small green area in the front. Yet, lack of green space and unsuccessful combination of it with the rest of the school yard is undeniable. Figure 6 shows that less than $10 \%$ of the hall yard is due to natural environment.

The other environmentally sustainable issue related to school yard is rain water restoration. It is important to note that Roshangar Primary School doesn't use main drainage system of Shahrak Gharb area for its yard irritation. Private water well with non purificated water is consumed for irrigation and washing purposes. Considering the hot-arid climate of Tehran with low annual rainfalls (Ghobadian, 1998), this consumption technique of Roshangar is highly valuable from environmental sustainability's view point. On the other hand, all of the figures related to the school yard (figure $4,5 \& 6$ ) clearly show that no provision of restoring rain water can be spotted in the entire yard, and therefore, it can be assumed that no rain water management has been taken place which is certainly a strong negative point due to climatic design's priorities. 


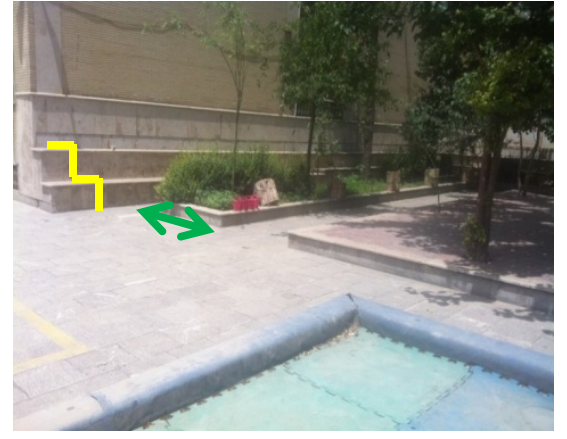

Figure 5. Green line at the sides of the school yard

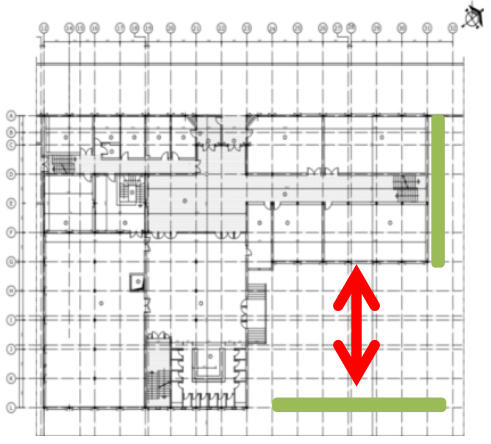

Figure 6. Green lines of the school yard

As shown in figure 7, School's main entrance is located at the side of a narrow valley in South Golafshan St. Roshangar Primary school's entrance is designed in relate to children's safety issues. The main entrance is in Golafshan St. which guides pupil through a narrow valley outside the school building. It is from the school valley that pupil can pass their second entrance and enter their school. This valley also serves as a parking space for school's employers. As shown in figure 8, this design idea can solve part of the parking need for employer's vehicles and bicycles, besides guaranteeing more safety for children, yet, it is obvious that the yard of Roshangar primary school is completely isolated from the rest of the world and children could not feel connected with the community from their school yard.

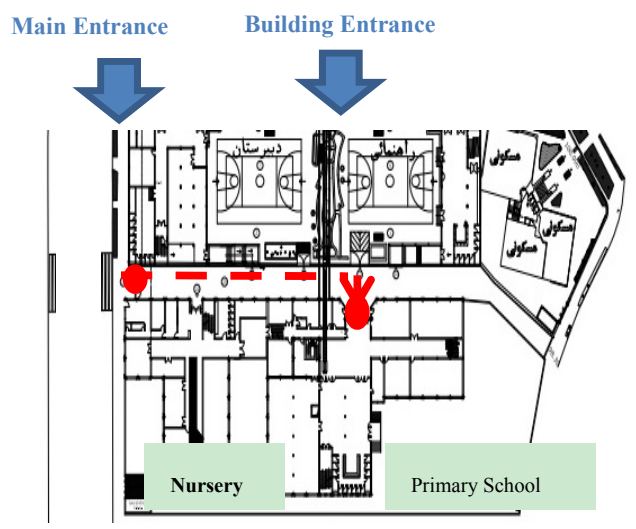

Figure 7. Double entrance of the school with a private valley will secure children's safety

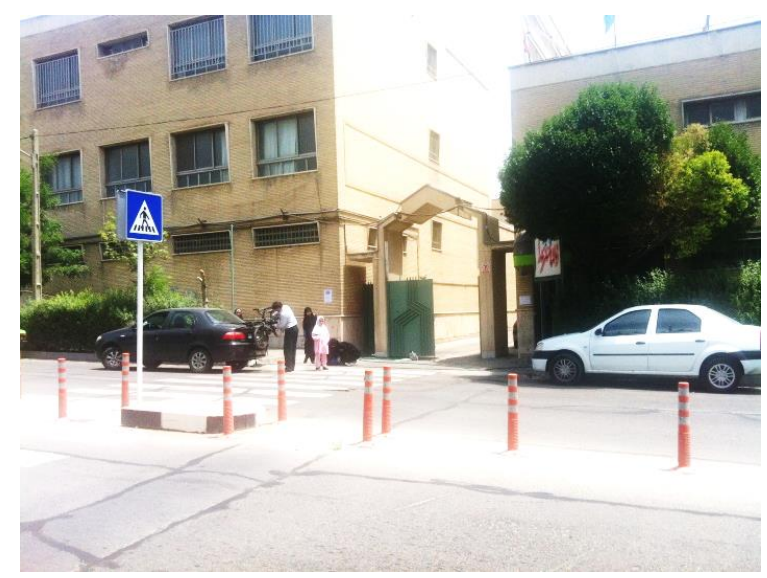

Figure 8. School's main entrance at the side of Golafshan St.

Central gardens are famous solutions of ancient Iranians in climatic architecture. They were usually constructed one level under the ground floor to meet the needed light and ventilation of the underground level floor, besides using earth's shelter against hot summer sun and cold winter winds. Central gardens are Iranian traditional and vernacular design features that apart from decreasing energy consumption, contain local architectural identity and can therefore play an important role in achieving the goals of sustainable architecture. All civilizations have their own vernacular techniques to achieve human comfort besides protecting natural environment. It is important to note that the use of traditional architectural features in the design of educational spaces is very effective in practicing indirect education of sustainable priorities. Central garden of Roshangar primary school is placed at the center of its underground floor, locating the main hall of the ground floor to the multi-functional hall in the lower floor. As shown in figure 9, central garden is surrounded by the windows of central hall, dining hall and the sports hall in different levels. It's bright, green scenery can also be observed from the corridors of higher levels. 


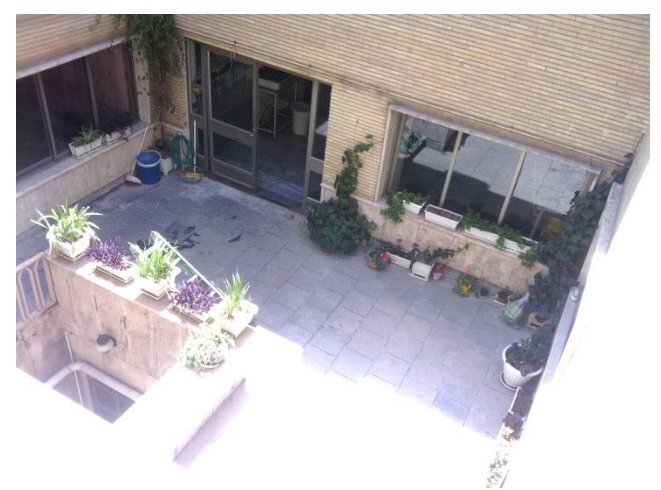

Figure 9. Central yard of the school

\section{Environmental Sustainability in Close Spaces of Roshangar Primary School}

The settlement direction of school building is north west-south east. This is the direction of Tehran's main wind and therefore designing a building in accordance to this direction will help natural ventilation in the close spaces. The designer of this school has designed wide corridors and linking spaces between the building entrance at the north-west side and the yard entrance at the south-east side. As shown in figure10, this design technique will allow natural ventilation within the linking spaces and decrease energy consumption. The building can also gain enough day lighting from three directions of north-west, south-east and south. The private valley and the central garden play an important role in this function (figure.10). The materials mostly used in this school consist of brick, concrete and stone, which are assumed as local materials for the city of Tehran. As shown in figure 11, regional materials can also be noticed in the closed space of Roshangar Primary School. Using local material is a necessity in environmental sustainable architecture and donates a positive point to this school. Lower embodied energy consumption and cultural identity are two main goals of local material consumption as a step towards climatic and more sustainable architecture (Bennetts, 2003).

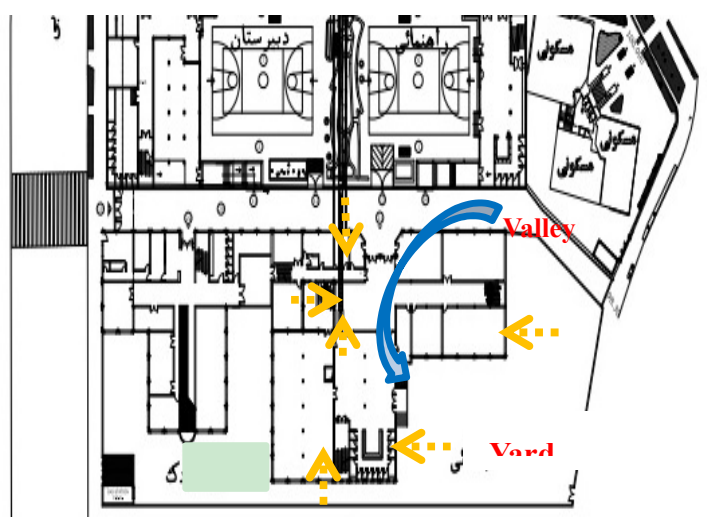

Figure 10. Natural ventilation and lighting in the school building

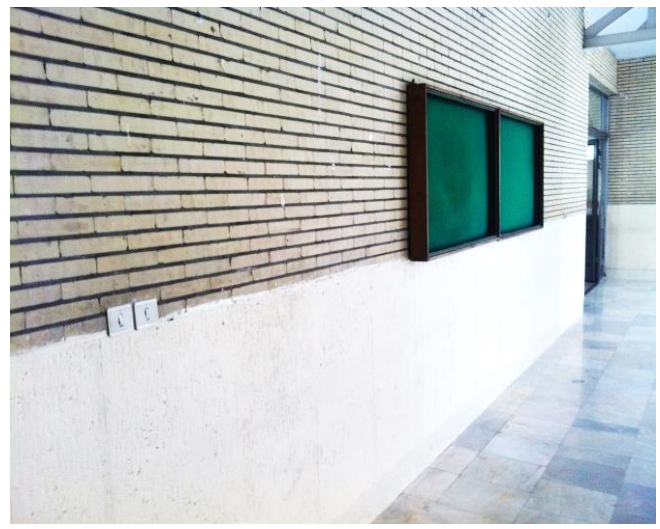

Figure 11. Use of local material in school design

Existence of multi-functional spaces, donates another positive point for Roshangar Primary School. Multi-functional space consideration is very important in realization of educational priorities in sustainable architecture (Dahl, 2013). There are two main multi-functional spaces in the school. First one is a hall in the first floor which is mostly used as gathering or meeting room, the second one is in the basement and is occasionally used as a sports hall. There are also other smaller multi-functional spaces such as the traditionally designed class room in the first floor (figure. 12). Wide Linking spaces of the school can also play as a multi-functional space in appropriate timings. The design of these linking spaces is also effective in child's creativity and quality of learning. Linking spaces such as corridors and stair ways should act as a space of movement. "They embody the movement circulation of mind, and terminate Movement or motionlessness, creativity or imitation ..." (Tominga, 1995). Yet, we can't notice creativity in Roshangar Primary School's linking spaces. Simple corridors and stare ways of this school obviously don't carry the ability of encouraging creativity in children. As shown in figure 13, Roshangar Primary School advantages from wide, bright linking spaces, yet, suffers from simplicity and lack of creativity in them (figure. 14). 


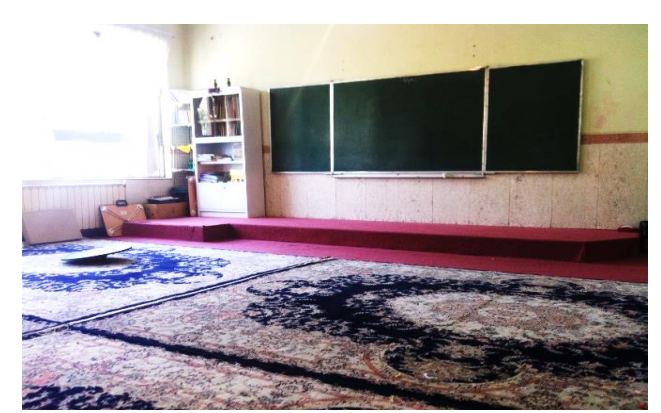

Figure 12. Multi-functional space with traditional design

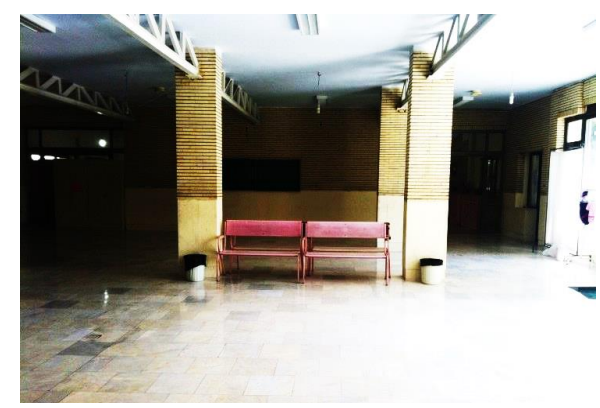

Figure 13. Wide linking space between the dining hall and the yard

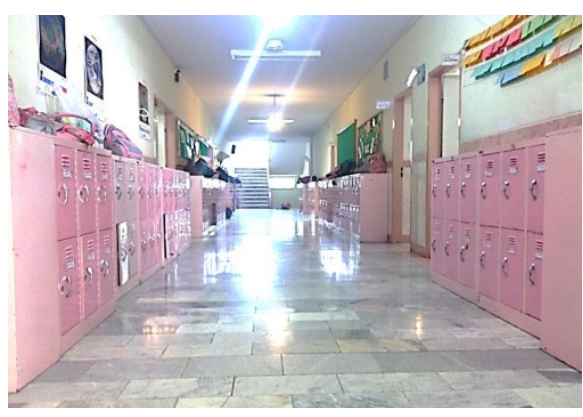

Figure 14. Simple corridor and stairway

The other important fact which is effective in child's learning and creativity is the class-room design. Closed, teacher-oriented class-room limits children's spirits and has negative effects on their creativity (Oblinger, 2005). This is while educational system in Iran's primary school is still focused on the above mentioned teaching system. Class rooms of Roshangar primary school is not an exemption in this field. Class rooms have closed and limited arrangement and don't encourage group activities, which, due to the recently studied teaching methods, is known to be the worst method of teaching responsibility and fostering creativity in young children (Khan Mohammadi 2009). While this design can have positive effects on children's concentration, it limits their incline and their ability for group activities and encourages their willingness for individual activities. Since group activities in one of the sustainable priorities in school design, it could be said that teacher oriented class-rooms of Roshangar Primary School are not sustainable (figure. 15). On the other hand, library has used an open design with more flexible arrangement, which is completely appropriate for group activities. As figure 16 shows, the design of library and the arrangements of its facilities are delightful and interesting for children of young age. Colorful walls, short book shelves and circle design of tables are excellent in encouraging group activities and increasing children's sense of independents.

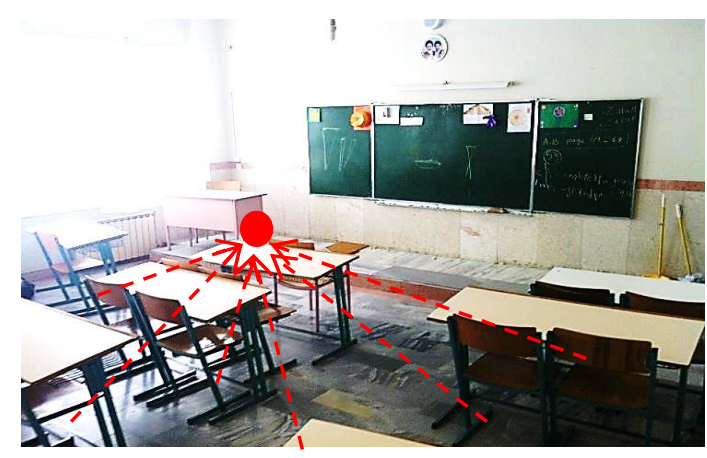

Figure 15. Teacher oriented class room of Roshangar

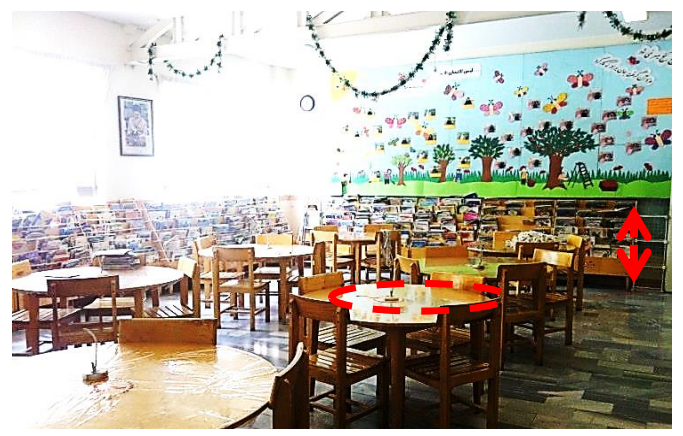

Figure 16. Library with flexible arrangement

Toilets and the washing rooms of Roshangar Primary School are completely old fashioned. Considering young children as the main users of these facilities and the fact that water consumption in this type of toilets is entirely dependent to the user's will, it could be strongly assumed that the design of school's toilets and wash rooms are not following environmental sustainable guide lines in order to reduce water consumption (figure 17). Mechanical, out dated rolling water taps shown in figure 18 are not sensible or smart enough to control water 
consumption or waste. Carelessness in choosing appropriate facilities and avoiding new technologies will due to a negative point for Roshangar Primary School.

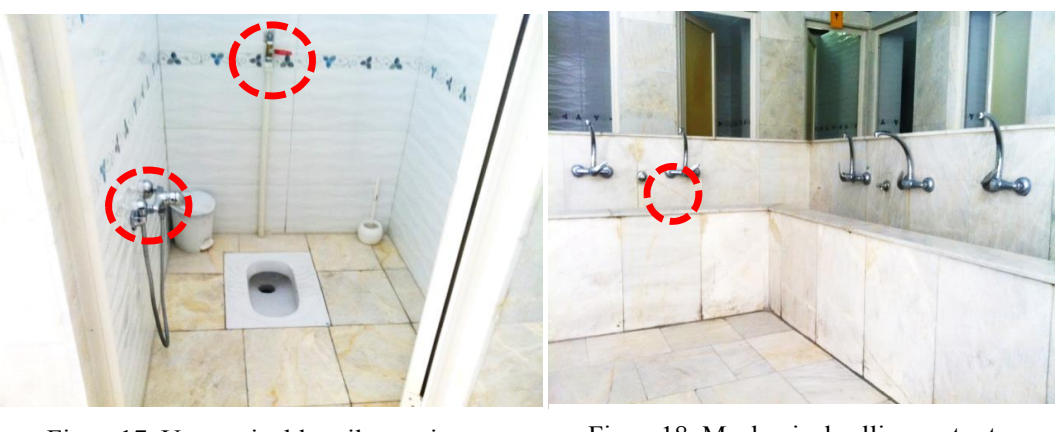

Figure17. Unsustainable toilet equipment

Figure18. Mechanical rolling water taps

\section{Result of Evaluating Environmental Sustainability in Roshangar Primary School}

Environmental sustainability in Roshangar School can be assessed based on LEED2009 guide line for schools (Appendix A). This assessment can illuminate the existing shortcomings in architectural environmental sustainability of Iranian schools and consequently, in the presented design principles. Table2 presents the result of this assessment.

Table 2. Similarities between guide line of LEED 2009 for school and architecture of Roshangar Primary School

\begin{tabular}{|c|c|c|}
\hline Main Branch & Guide line of LEED2009 for Schools & $\begin{array}{c}\text { Environmental Sustainability in } \\
\text { Roshangar Primary School }\end{array}$ \\
\hline $\begin{array}{l}\text { Sustainable } \\
\text { site }\end{array}$ & $\begin{array}{l}\text { Construction activity pollution prevention (obligatory)- Correct site } \\
\text { selection - Access to optimum density in build environments and } \\
\text { adjacent to urban servitudes system - Renovation of damaged sites and } \\
\text { environmental pollutions - Providing appropriate public transportation } \\
\text { access - Providing space for bicycle storage and changing rooms - } \\
\text { Using low-emitting and fuel-efficient vehicles - Creating appropriate } \\
\text { parking capacity- Protection or restoring of animal habitat - } \\
\text { Maximizing open space - Rain quantity management - Rain quality } \\
\text { management - Heat island prevention in non-roof - Heat island } \\
\text { prevention in roof - Light pollution reduction - Site development plan - } \\
\text { Multipurpose use of facilities }\end{array}$ & $\begin{array}{l}\text { Providing space for bicycle } \\
\text { storage and changing rooms }\end{array}$ \\
\hline Water & Water use reduction (obligatory) - Saving water in irrigation systems - & \\
\hline $\begin{array}{l}\text { Efficiency } \\
\text { (WE) }\end{array}$ & $\begin{array}{l}\text { Recycling water through innovative technologies- More reduction of } \\
\text { water use }\end{array}$ & \\
\hline $\begin{array}{l}\text { Energy and } \\
\text { Atmosphere } \\
\text { (EA) }\end{array}$ & $\begin{array}{l}\text { Ensuring accurate performance of Building Energy Systems } \\
\text { (obligatory)- Minimum building Energy use (obligatory)- Prevention } \\
\text { from ozone layer depletion through cooling facilities (obligatory)- } \\
\text { Optimizing building energy use - In site renewable energy sources use } \\
\text { - More assurance of systems and building elements correct } \\
\text { performance - Full prevention from ozone layer depletion through } \\
\text { refrigerant facilities - Measurement and verification of energy in } \\
\text { buildings - Using green powers }\end{array}$ & ----- \\
\hline $\begin{array}{l}\text { Materials and } \\
\text { Resources } \\
\text { (MR) }\end{array}$ & $\begin{array}{l}\text { Storage and collection of Recyclables (obligatory)- Building reuse by } \\
\text { maintaining existing walls and floors - Building Reuse by maintaining } \\
\text { interior nonstructural elements - Construction waste management - } \\
\text { Building materials use - Recyclable elements use - Local and regional } \\
\text { materials use - Rapidly renewable materials use - Certified wood use }\end{array}$ & $\begin{array}{l}\text { Local and regional materials } \\
\text { use }\end{array}$ \\
\hline $\begin{array}{l}\text { Indoor } \\
\text { Environmental } \\
\text { Quality (IEQ) }\end{array}$ & $\begin{array}{l}\text { Minimum building indoor air desired quality access (obligatory)- } \\
\text { Environmental tobacco smoke (ETS) control (obligatory) - Increased } \\
\text { ventilation - } \mathrm{Co}_{2} \text { measuring systems installation - Indoor air quality } \\
\text { management plan during construction - Construction indoor air quality }\end{array}$ & Natural light provision \\
\hline
\end{tabular}


management plan before occupancy - Low-emitting pollutants, glues, caulkers - Low-emitting pollutants, colors, and coatings - Low-emitting pollutants, flooring - Low-emitting pollutants, timber products - Indoor Chemical and biological pollutants and dangerous particles Control Controllability of lighting systems - Controllability of thermal and conditioning systems - Thermal comfort system design - Thermal comfort system verification - Natural light provision - Appropriate light provision

\begin{tabular}{clc}
\hline $\begin{array}{c}\text { Innovation in } \\
\text { Design (ID) }\end{array}$ & $\begin{array}{l}\text { Innovation in design - LEED associated design - School as a teaching } \\
\text { tool }\end{array}$ & $\begin{array}{c}\text { Innovation in design and using } \\
\text { traditional features }\end{array}$ \\
\hline $\begin{array}{c}\text { Regional } \\
\text { Priorities (RP) }\end{array}$ & Regional and local priorities importance & $\begin{array}{c}\text { Regional and local priorities } \\
\text { importance }\end{array}$ \\
\hline
\end{tabular}

Existing figures show that facilities, sports and multifunctional spaces have been provided in this school. However, its green, natural space is so limited and there is no picture of rainwater management or appropriate parking space. In addition, Roshangar Primary School has taken important steps toward sustainability in materials and sources by using regional materials. Innovation in design is also seen in some parts of the school. In regards to indoor space quality, Roshangar School has been successful in natural light provision. On the other hand, the school is not equipped with appropriate bathroom equipment and therefore, will not be able to control its water consumption and waste.

Overall, Roshangar School can't be considered as an educational device and has not provided the possibility of teaching indirect environmental sustainability to its pupil. In fact, it has considered the primary school structure as a dead physical body including wall, ceiling, and floor. In this school, the structure and space does not have any educational function and is merely considered for teaching predetermined courses.

\section{Discussion and Recommendation}

\subsection{Shortcomings of Design Principles in Iranian Primary School Design}

This study shows that State Organization of School Renovation has only few points in common with "LEED 2009 for school" which are all due to the branch of 'Sustainable Site'. These points are limited to five items in outdoor space and one item in indoor space (refer to table 1). This is while Environmental Sustainability guideline of LEED is described under seven main branches. (Appendix1).

Visual analysis of Roshangar Primary School show another three in common items between LEED and State Organization of School Renovation; Using regional materials and natural light provision were observed in this primary school and are the subsets of "materials and sources" and "indoor building quality" branch. In addition, architectural design of this building is not inattentive to the branch of "innovation in design". However, in order to reach environmental sustainability in the architecture of Iranian primary schools, all international guidelines of environmental sustainability need to be followed completely. The following shortcomings are discovered in the design principles of State Organization of School Renovation on the grounds of international guideline of "LEED for school":

- Insufficient attention to the pollution caused in the process of school construction

- Insufficient attention to rain water management

- Insufficient attention to heat island and light pollution in school

- Insufficient attention to decrease water consumption

- Insufficient attention to save energy use in school building

- Insufficient attention to use of renewable energy

- Insufficient attention to save recyclable materials

- Insufficient attention to use low hidden energy materials

- Insufficient attention to control chemical and biological pollutants

- Insufficient attention to provide appropriate landscaping

- Insufficient attention to innovation in design

- No consideration in promoting a primary school building to an educational device 4.2 Recommendation

The discovered shortcomings of this study can be a serious alarm for responsible Iranian architects and decision makers. They show the importance of pursuing an environmental sustainable approach in Iranian Design 
Principles. In addition, by discovering the existing shortcomings of Iranian design principles, the possibility of recommending strategies and promoting new design principles based on the recognized priorities are provided and eventually the shortcomings can be fulfilled. Finally, a set of recommendations are presented in table 3 . The concluded suggestions can strongly guide to improvement in the design principles of Iranian Primary Schools.

Discovering the existing shortcomings in principles requires full understanding and recognition of patterns and priorities in environmental sustainability. This recognition can be considered as the most initial and effective step for achieving environmental sustainability in primary school architecture. Findings of this study - the shortcomings of design principle of State Organization of School Renovation in Iran, based on environmental sustainability - and effective recommendations it concluded, can provide the basis of creation for a Sustainable Educational Architecture in Iran.

Table 3. Shortcomings and recommendations

\begin{tabular}{|c|c|}
\hline Shortcomings & Recommendations \\
\hline $\begin{array}{l}\text { Insufficient attention to environmental } \\
\text { sustainability in school yard }\end{array}$ & $\begin{array}{l}\text { Correct selection of site, access to optimum density in built environments } \\
\text { and adjacent to public transport system, protecting or restoring animal } \\
\text { habitat, paying attention to local and regional priorities }\end{array}$ \\
\hline $\begin{array}{l}\text { Insufficient attention to pollution caused } \\
\text { while building the school }\end{array}$ & $\begin{array}{l}\text { Prevention of causing pollution by constructional activities, Renovation of } \\
\text { damaged and pollutant sites, using low-emitting and fuel-efficient vehicles }\end{array}$ \\
\hline $\begin{array}{l}\text { Insufficient attention to rain water } \\
\text { management }\end{array}$ & quantitative management of rain, qualitative management of rain \\
\hline $\begin{array}{l}\text { Insufficient attention to heat island and light } \\
\text { pollution in school }\end{array}$ & $\begin{array}{l}\text { Heat island prevention in non-roof, heat island prevention in roof, light } \\
\text { pollution reduction }\end{array}$ \\
\hline Insufficient attention to save water use & $\begin{array}{l}\text { Reduction of water consumption by using efficient equipment, restoring rain } \\
\text { or used water for irrigation systems, recycling water through related } \\
\text { technologies }\end{array}$ \\
\hline $\begin{array}{l}\text { Insufficient attention to save energy use in } \\
\text { school building }\end{array}$ & $\begin{array}{l}\text { Ensuring accurately from the performance of energy systems in the school } \\
\text { building, prevention of ozone layer depletion through cooling/heating } \\
\text { facilities, optimizing energy use in the school building, frequently measure } \\
\text { the energy consumption in school buildings, keeping control over ventilation } \\
\text { and thermal systems }\end{array}$ \\
\hline Insufficient attention to use renewable energy & Using renewable energy sources, using green energies \\
\hline $\begin{array}{l}\text { Insufficient attention to save recyclable } \\
\text { materials }\end{array}$ & Save \\
\hline $\begin{array}{l}\text { Insufficient attention to use low hidden } \\
\text { energy materials }\end{array}$ & $\begin{array}{l}\text { Construction waste management, reusing the building materials, using } \\
\text { recyclable materials, using rapidly renewable materials }\end{array}$ \\
\hline $\begin{array}{l}\text { Insufficient attention to control chemical and } \\
\text { biological pollutants }\end{array}$ & $\begin{array}{l}\text { Environmental Tobacco Smoke (ETS) control, installation of } \mathrm{co}_{2} \text { measuring } \\
\text { systems for building's exhausting air, increasing ventilation and } \\
\text { air-conditioning system, low-emitting pollutants, glues and caulkers, colors } \\
\text { and coatings, flooring, timber products, controlling the chemical and } \\
\text { biological pollutants and dangerous particles in indoor space }\end{array}$ \\
\hline $\begin{array}{l}\text { Insufficient attention to provide appropriate } \\
\text { green and natural space }\end{array}$ & Provision of appropriate green and natural space \\
\hline Insufficient attention to innovation in design & Innovation in design \\
\hline $\begin{array}{l}\text { No consideration of primary school as an } \\
\text { educational device }\end{array}$ & School as an educatic \\
\hline
\end{tabular}

\section{References}

Beer, a. (2000). Environmental Planning for Site Development. New York: Taylor \& Francis.

Bennetts, H. (2003). Understanding sustainable architecture. London: Taylor \& Francis.

Curlwell, S. (2005). The frame work and protocols for environmental assessment. London: Routledge Publication.

Dahl, A. L. (2013). Achievements and gaps in indicators for sustainability. Ecological Indicators, 17, 14-19. 
Dresner, S. (2008). Priciples of Sustainability. London Routledge Publication.

Ghobadian, V. (1998). Analyzing vernacular Iranian architecture. Tehran: Publication of Tehran University.

Khan Mohammadi, M. A. (2014). Theoretical enhancement of sustainable architecture from Islamic points of view. Tehran: Iran University of Science and Technology.

Lahsayeezadeh, A. (2007). Sociology of development (Fifth ed.). Tehran: Payam Noor University.

Lynch, K., \& Hack, G. (1984). Site Planning. United States of America: The MIT Press.

Nair, P., \& Fielding, R (2005). The Language of School Design, Design for 21st Century Schools. London: Design Share.

Oblinger, D. (2005). Leading the transition from classrooms to learning Spaces. London: Educause Quarterly.

Sassi, P. (2006). Strategies for Sustainable Architecture. New York: Taylor \& Francis.

State Organization of School Renovation Development and mobilization; Architectural Group. (2009). Design principle of educational spaces. Tehran: Ministry of Education.

Stevenson, K. R. (2002). Ten Educational Trends Shaping School Planning and Design. from National Clearinghouse for Educational Facilities. Retrieved from http://www.ncef.org/pubs/trends2007.pdf

Tominga, Y. (1995). Educational facilities, New Concept in architecture and design. Tokyo: Mei Sei Publication.

Zahedi, S. (2014). Sustainable Development. Tehran: Parham Publication.

\section{Appendix A}

LEED for School

\begin{tabular}{|c|c|}
\hline Main Branch & Guide line of LEED2009 for schools \\
\hline Sustainable site & $\begin{array}{l}\text { Construction activity pollution prevention (obligatory) - Correct site selection - Access to optimum density in build } \\
\text { environments and adjacent to urban servitudes system - Renovation of damaged sites and environmental pollutions } \\
\text { - Providing appropriate public transportation access- Providing space for bicycle storage and changing rooms - } \\
\text { Using low-emitting and fuel-efficient vehicles - Creating appropriate parking capacity - Protection or restoring of } \\
\text { animal habitat - Maximizing open space - Rain quantity management - Rain quality management - Heat island } \\
\text { prevention in non-roof - Heat island prevention in roof - Light pollution reduction - Site development plan - } \\
\text { Multipurpose use of facilities }\end{array}$ \\
\hline $\begin{array}{l}\text { Water Efficiency } \\
\text { (WE) }\end{array}$ & $\begin{array}{l}\text { Water use reduction (obligatory) - Saving water in irrigation systems - Recycling water through innovative } \\
\text { technologies - More reduction of water use - }\end{array}$ \\
\hline $\begin{array}{l}\text { Energy and } \\
\text { Atmosphere (EA) }\end{array}$ & $\begin{array}{l}\text { Ensuring accurate performance of Building Energy Systems (obligatory) - Minimum building Energy use } \\
\text { (obligatory) - Prevention from ozone layer depletion through cooling facilities (obligatory) - Optimizing building } \\
\text { energy use - In site renewable energy sources use - More assurance of systems and building elements correct } \\
\text { performance - Full prevention from ozone layer depletion through refrigerant facilities - Measurement and } \\
\text { verification of energy in buildings - Using green powers }\end{array}$ \\
\hline $\begin{array}{l}\text { Materials and } \\
\text { Resources (MR) }\end{array}$ & $\begin{array}{l}\text { Storage and collection of Recyclables (obligatory) - Building reuse by maintaining existing walls and floors - } \\
\text { Building Reuse by maintaining interior nonstructural elements - Construction waste management - Building } \\
\text { materials use - Recyclable elements use - Local and regional materials use - Rapidly renewable materials use - } \\
\text { Certified wood use }\end{array}$ \\
\hline $\begin{array}{l}\text { Indoor } \\
\text { Environmental } \\
\text { Quality (IEQ) }\end{array}$ & $\begin{array}{l}\text { Minimum building indoor air desired quality access (obligatory) - Environmental tobacco smoke (ETS) control } \\
\text { (obligatory) - Increased ventilation - } \mathrm{Co}_{2} \text { measuring systems installation - Indoor air quality management plan } \\
\text { during construction - Construction indoor air quality management plan before occupancy - Low -emitting } \\
\text { pollutants, glues, caulkers - Low-emitting pollutants, colors, and coatings - Low-emitting pollutants, flooring - } \\
\text { Low-emitting pollutants, timber products - Indoor Chemical and biological pollutants and dangerous particles } \\
\text { Control - Controllability of lighting systems - Controllability of thermal and conditioning systems - Thermal } \\
\text { comfort system design - Thermal comfort system verification - Natural light provision - Appropriate light provision }\end{array}$ \\
\hline $\begin{array}{l}\text { Innovation in Design } \\
\text { (ID) }\end{array}$ & Innovation in design - LEED associated design - School as a teaching tool \\
\hline $\begin{array}{l}\text { Regional Priorities } \\
\text { (RP) }\end{array}$ & Regional and local priorities importance \\
\hline
\end{tabular}

Source: www.leed.net 


\section{Appendix B}

Summary of Closed Spaces Data of Iran Primary School

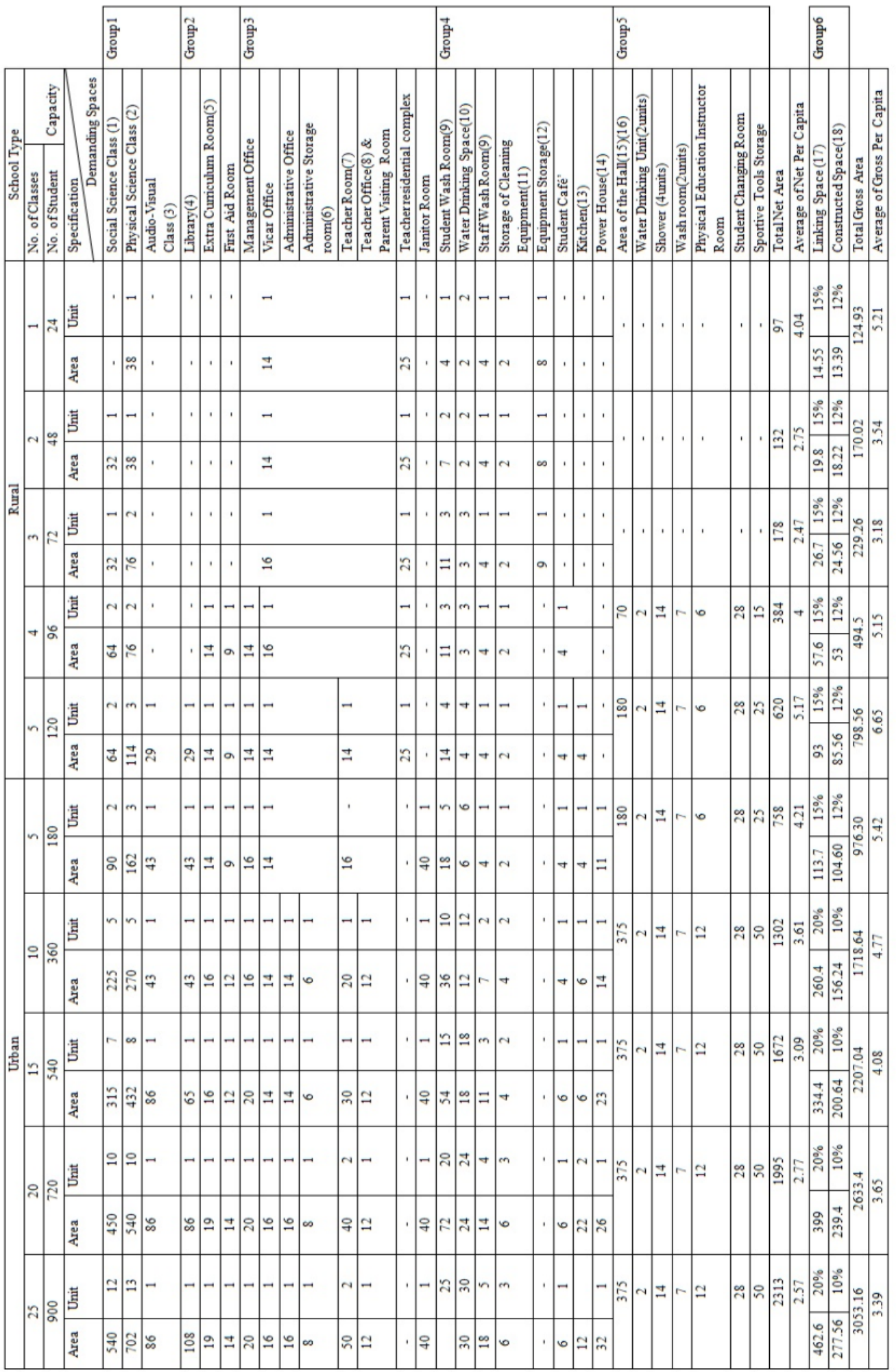

Source: State Organization of School Renovation Development and mobilization; Architectural Group (2013, p. 5) 


\section{Appendix C}

Required Open Space in Iran Primary School

\begin{tabular}{|c|c|c|c|c|c|c|c|c|c|c|}
\hline \multirow{2}{*}{$\begin{array}{c}\text { School Type } \\
\text { Number of classes }\end{array}$} & \multicolumn{5}{|c|}{ Rural } & \multicolumn{5}{|c|}{ Urban } \\
\hline & 1 & 2 & 3 & 4 & 5 & 5 & 10 & 15 & 20 & 25 \\
\hline Number of student & 24 & 48 & 72 & 96 & 120 & 180 & 360 & 540 & 720 & 900 \\
\hline $\begin{array}{c}\text { Demanding Queue up space and } \\
\text { playground (1) }\end{array}$ & 136 & 136 & 136 & 136 & 136 & 288 & 576 & 846 & 1152 & 1440 \\
\hline Demanding Sport's field (2) & & & & & & & & & & \\
\hline $\begin{array}{c}\text { Demanding Landscape, flower boxes } \\
\text { and trees (3) }\end{array}$ & 12 & 24 & 36 & 48 & 60 & 60 & 108 & 162 & 216 & 270 \\
\hline Demanding Parking space(4) & 25 & 30 & 35 & 40 & 45 & 45 & 70 & 95 & 120 & 145 \\
\hline $\begin{array}{l}\text { Demanding Linking path for public } \\
\text { transport, Preserving space for future } \\
\text { development (5) }\end{array}$ & 17 & 19 & 21 & 22.5 & 24 & 39 & 75.5 & 110.5 & 149 & 185.5 \\
\hline $\begin{array}{l}\text { Total demanded area of the open space } \\
\text { (6) }\end{array}$ & 190 & 209 & 228 & 246.5 & 265 & 432 & 829.5 & 1213.5 & 1637 & 2040.5 \\
\hline Area per capita & 7.91 & 4.35 & 3.16 & 2.55 & 2.20 & 2.4 & 2.30 & 2.25 & 2.27 & 2.27 \\
\hline
\end{tabular}

Source: State Organization of School Renovation Development and mobilization; Architectural Group (2013, p. 7)

\section{Explanation}

1. Needed space for student to queue is 1.6 square meter per student, and the space needed for the morning exercise is 1.7 square meter in average. Yet, because of land limitations in urban spaces, in the above table, the biggest number for per capita of queue area (1.6 square meters) is considered as the basis for calculation of sport's Field.

2. In schools with up to 120 capacities (rural), because the total area of queue space is less than volleyball mini playground, in calculation of the open space in the school, the mini volleyball playground (136 square meters) has been considered.

3. This part includes garden, planting, growing vegetables and allocating a part of garden for growing vegetables by students. The $30 \%-50 \%$ square meter has been considered as Per capita for landscape in schools.

4. Twenty-five square meters is needed for one class, and for every extra class, an extra 5 Meters should be considered.

5. The $10 \%$ of the above area should be considered for linking spaces, waste spaces and preserved spaces for further developments.

The custodianship and student washrooms areas, which are built outside of the school building and in the school area, should be included in the open space area and should be totally considered in the land per capita table.

\section{Copyrights}

Copyright for this article is retained by the author(s), with first publication rights granted to the journal.

This is an open-access article distributed under the terms and conditions of the Creative Commons Attribution license (http://creativecommons.org/licenses/by/3.0/). 